\title{
Pengaruh Petugas Tidak Resmi Terhadap Lalu Lintas Pada Simpang Tiga Bersinyal di Jl. Kaliuang KM. 8 Yogyakarta
} (The Effect of Unofficial officer at Unsignalized Intersection)

\author{
Prima J. Romadhona ${ }^{1^{*}}$, Umi Nur Chasanah ${ }^{1}$ \\ ${ }^{1}$ Program Studi Teknik Sipil, Fakultas Teknik Sipil dan Perencanaan, Universitas Islam Indonesia. \\ Jl. Kaliurang KM 14,5 Yogyakarta, Indonesia \\ * Penulis Korespondensi: prima_dhona@uii.ac.id
}

\begin{abstract}
The congestion at the PLN intersection Kaliurang street Km 8 is the reason of Unofficial Officers or so-called "Pak Ogah" act as traffic regulators or assist in the movement of driving from minor roads to major roads. Therefore, the objective of the study was to determine the impact of Unofficial Officers on the performance of intersections. The survey was conducted for 3 days which were volume survey, a survey of vehicle speed, driving behavior, and length of the queue. VISSIM modeling analysis results showed that using signals was better than existing conditions with a decrease in the average delay value of $18.44 \%$ and a decrease in the average queue length of $80.34 \%$. Meanwhile, the condition of intersections with unofficial officers decreased by an average delay of $22.10 \%$ compared to existing conditions. However, the average queued length by unofficial officers increased by 22.54\% compared to existing conditions. Although the results of delays with Unofficial Officers were better than other conditions, arrangements by unofficial officers had many conflicts, creating the risk of accidents at the intersection.
\end{abstract}

Keywords: Unofficial officer, Delay, Queue Length, VISSIM, signal intersection

\section{PENDAHULUAN}

Petugas tidak resmi saat ini sering dijumpai pada simpang tidak bersinyal. Petugas Tidak Resmi sering disebut "Pak Ogah". Simpang tak bersinyal yang terdapat PTR salah satunya pada Simpang PLN Jakal Km 8. Simpang PLN Jakal Km 8 merupakan kelas jalan Kolektor yaitu menghubungkan jalan antar kota menuju tempat wisata yang ada di Yogyakarta. Simpang PLN Jakal Km 8 dilewati oleh kendaraan ringan sampai kendaraan berat. Dengan volume lalu lintas pada cukup tinggi, serta terdapat aktivitas pada lengan persimpangan yaitu adanya pertokoan, wisata kuliner, dekat dengan sekolah sehingga menyebabkan Simpang PLN terjadi kemacetan. Simpang PLN Jakal $\mathrm{Km} 8$ termasuk simpang prioritas yang memiliki karakteristik arus kendaraan pada jalan utama (mayor) mendapat prioritas terlebih dahulu dan tidak dilengkapi oleh alat pemberi isyarat lampu lalu lintas.

Persimpangan prioritas tidak dilengkapi dengan APILL sehingga pada saat jam sibuk mengakibatkan pengendara kendaraan dari jalan minor harus antri lama dan kemacetan untuk menyebrang ke jalan mayor karena jalan mayor lebih diutamakan. Volume lalu lintas yang tinggi tanpa pengaturan dapat mempengaruhi kinerja simpang ketika jam sibuk.

Dengan kondisi simpang yang ramai maka PTR mengambil peran untuk membantu perpindahan kendaraan dari jalan minor ke jalan mayor. PTR mengambil alih peran polisi yang mana bertugas sebagai pengatur lalu lintas. Sebagai pengatur lalu lintas dengan mengharapkan imbalan dari pengendara yang telah dibantu untuk perpindahan dari jalan minor ke jalan mayor. Imbalan yang diharapkan tergantung pengendara dengan nominal seikhlasnya. 
Munculnya kejadian tersebut menimbulkan konflik sosial pada persimpangan. Konflik sosial akibat adanya PTR di persimpangan yaitu adanya ancaman pengendara untuk memberikan imbalan kepada PTR. Selain itu juga menyebabkan simpang PLN mengalami panjang antrian akibat pemberhentian paksa pada jalan mayor. Dampak lain yang disebabkan yaitu menyebabkan konflik antar pengendara karena keinginan saling mendahului di persimpangan. Dampak diatas terjadi akibat kurangnya pengetahuan mengenai tata cara pengaturan pada lalu lintas. Menurut The Strait Times yang terdapat dalam Nursalam dan Akhir (2016), Pak Ogah (illegal traffic wardens) merupakan pengatur lalu lintas tidak resmi yang biasanya berada di pertigaan (T-junctions), di putaran jalan ( $U$ turns) dan persimpangan rel kereta api.

Al Qadri (2006) meneliti mengenai kinerja lalu lintas dan perilaku arus lalu lintas terhadap kinerja pengatur lalu lintas di persimpangan prioritas pada saat arus sibuk. Penelitian ini menggunakan metode analisa gelombang kejut untuk mendapatkan gerakan perubahan arus lalu lintas di persimpangan prioritas yang mendapat hambatan.

Selain itu, Romadhona dan Yuliansyah (2018) serta Verawanti dan Romadhona (2019) pernah melakukan penelitian tentang perbedaan kinerja simpang dengan kondisi pengaturan petugas tidak resmi dan tanpa pengaturan petugas tidak resmi dengan menggunakan software VISSIM. Pada penelitian tersebut mereka membandingkan output hasil dari permodelan VISSIM berupa panjang antrean dan waktu tundaan.

\section{SIMPANG TAK BERSINYAL}

Menurut Direktorat Jenderal Perhubungan Darat (1996) persimpangan merupakan adalah simpul dalam jaringan transportasi dimana dua atau lebih ruas jalan bertemu. Pada persimpangan arus lalu lintas mengalami konflik karena mempertemukan kendaraan dari berbagai lengan simpang, sehingga pada simpang pengemudi harus berhati-hati dan harus menentukan arah mana yang akan ditempuh, apakah jalan lurus, berbelok atau berpindah jalan.

Menurut Morlok (1988) Simpang jalan tanpa sinyal tidak ada sinyal lampu lalu lintas, sehingga pemakai jalan harus memutuskan apakah aman atau harus berhenti dahulu ketika akan melewati simpang tersebut.

Penelitian mengenai solusi simpang tak bersinyal telah dilakukan oleh Arisandi (2015), Kulo dkk (2017), Sugiharti dan Widodo (2013), Utama (2006), Wardhana dan Hartantyo (2016), Alhadar (2011) dengan menggunakan metode perhitungan Direktorat Jenderal Bina Marga (1997). Mereka telah meneliti pada simpang tidak bersinyal dengan kinerja buruk dan mengusulkan beberapa alternatif solusi diantaranya pemasangan rambu APILL (sinyal, rambu), pelebaran jalan, dan larangan belok kanan.

Selain itu, Saputro dkk, (2018) dan Tahjudin (2017) juga melakukan penelitian tentang kajian simpang tiga tak bersinyal menjadi simpang bersinyal menggunakan software VISSIM. Pada penelitian tersebut dilakukan simulasi permodelan persimpangan secara akurat pada kondisi eksisting dan pemodelan dengan pemasangan APILL.

\section{LEVEL OF SERVICE (LOS)}

Menurut Pemerintah Republik Indonesia, 2015, Tingkat pelayanan adalah kemampuan ruas jalan dan persimpangan untuk menampung lalu lintas pada keadaan tertentu. Yang mencakup tingkat pelayanan antara lain:

1. rasio antara volume dan kapasitas jalan,

2. kecepatan yang merupakan kecepatan batas atas dan kecepatan batas bawah yang ditetapkan berdasarkan kondisi daerah,

3. waktu perjalanan,

4. kebebasan bergerak,

5. keamanan,

6. keselamatan,

7. ketertiban,

8. kelancaran,

9. penilaian pengemudi terhadap kondisi arus lalu lintas. 
Berdasarkan Pemerintah Republik Indonesia, 2015, klasifikasi tingkat pelayanan pada persimpangan adalah sebagai berikut.

1. Tingkat pelayanan A (kondisi tundaan $<$ 5 detik/kendaraan)

2. Tingkat pelayanan B (kondisi tundaan $>$ 5 detik/kendaraan)

3. Tingkat pelayanan $\mathrm{C}$ (kondisi tundaan antara $>15 \mathrm{detik} /$ kendaraan sampai 25 detik/kendaraan)

4. Tingkat pelayanan D (kondisi tundaan $>$ 25 detik/kendaraan sampai 40 detik/kendaraan)

5. Tingkat pelayanan E (kondisi tundaan $>$ $40 \mathrm{detik} /$ kendaraan sampai 60 detik/kendaraan)

Tingkat pelayanan $\mathrm{F}$ (kondisi tundaan $>$ $60 \mathrm{detik} /$ kendaraan)

\section{PETUGAS TIDAK RESMI}

Menurut Pemerintah Republik Indonesia (2009), terdapat dua lembaga resmi di Indonesia yang berperan dalam mengatur lalu lintas yaitu Petugas Dinas Perhubungan dan Polisi Lalu Lintas (Polantas). Kemacetan pada simpang tak bersinyal dimanfaatkan oleh petugas tidak resmi untuk membatu perpindahan kendaraan dengan mengharap imbalan dari pengendara. Akan tetapi dengan keberadaan petugas tidak resmi pada simpang tak bersinyal menuai pro dan kontra pada kalangan pengendara. Keberadaan Pak Ogah bisa membantu kerja aparat kepolisian dalam pengaturan jalan lalu lintas. Selain itu aktivitas Pak Ogah justru dianggap mengganggu kondusivitas lalu lintas karena bertindak sesuai dengan keinginannya, bukan pada faktor kelancaran dan keamanan lalu lintas, Tirtana (2018). Selain itu Pak Ogah ini justru mengatur lalu lintas berdasarkan alasan komersil, seharusnya tidak ada yang seperti itu, YUD (2018). Pak Ogah memberi layanan atau bantuan prioritas kepada pengendara (yang hendak putar balik), dimana posisi Pak Ogah itu berada di sisi pengemudi (roda empat) duduk, padahal itu sangat menyalahi ketentuan. Posisi Pak Ogah yang berada di dekat pengemudi mobil saat membantu kendaraan memutar balik dapat membuat kecelakaan. Benturan dapat saja terjadi antara kendaraan yang hendak putar balik dengan kendaraan yang berada di jalur prioritas, atau kendaraan yang ditahan untuk mengalah karena ada kendaraan tengah putar balik. Hal itu terjadi karena ketidaktahuan Pak Ogah mengenai tata cata pengaturan lalu lintas yang benar sehingga akan memunculkan bahaya pada lalu lintas, Antony (2019), Antony (2020).

\section{PTV VISSIM}

Permodelan adalah suatu proses peniruan dari sesuatu yang nyata beserta dengan keadaan di sekelilingnya. Aksi melakukan simulasi ini secara umum menggambarkan sifat-sifat karakteristik kunci dari kelakuan sistem fisik atau sistem yang abstrak tertentu (Aryandi \& Munawar, 2014). VISSIM adalah software yang berasal dari Jerman yang digunakan untuk mensimulasikan lalu lintas multi-modal mikroskopik, transportasi umum bahkan pejalan kaki. VISSIM juga dipilih untuk mengkalibrasi kondisi lalu lintas.

Kalibrasi pada software VISSIM merupakan proses dimana upaya untuk menyesuaikan model simulasi dengan model yang sesuai di lapangan dengan tujuan untuk mencapai model simulasi secara akurat yang sama atau mendekati model pada lapangan. Proses kalibrasi dilakukan berdasarkan perilaku pengemudi yang telah diamati. Validasi pada VISSIM merupakan proses pengujian kebenaran dari kalibrasi dengan membandingkan volume hasil observasi dan hasil simulasi. Metode Geoffrey E. Havers (GEH) digunakan untuk validasi volume kendaraan yang merupakan persamaan statistik hasil modifikasi dari rumus Chi - squared. Persamaan statistik GEH digunakan untuk membandingkan dua volume lalu lintas yaitu volume kendaraan observasi dan volume kendaraan yang dimodelkan. Proses kalibrasi yang disyaratkan pada PTV VISSIM hanya volume lalu lintas. 
$G E H=\sqrt{\frac{(q \text { simulated }-q \text { observed })^{2}}{0,5 \times(q \text { simulated }+ \text { qobserved })}}$

$\begin{array}{ll}\text { dengan: } & \\ \mathrm{q}_{\text {simulated }}= & \text { data volume lalu lintas } \\ & (\text { kendaraan/jam) } \\ & \text { VISSIM } \\ = & \text { data volume lalu lintas } \\ & (\text { kendaraan/jam) hasil } \\ & \text { pengamatan. }\end{array}$

Hasil perhitungan rumus statistik GEH mempunyai ketentuan sebagai berikut.

1. Hasil $G E H<5$, kondisi permodelan memenuhi (diterima).

2. Hasil GEH diantara 5 - 10, kondisi permodelan perlu di cek ulang kemungkinan model eror.

3. Hasil $G E H>10$, kondisi permodelan tidak memenuhi (ditolak).

\section{METODE PENELITIAN}

Pengumpulan data pada penelitian ini dilakukan di lapangan antara lain survei volume kendaraan, survei kecepatan kendaraan, survei driving behavior, survei panjang antrean dan geometri simpang. Survei volume kendaraan lalu lintas dilakukan dengan menghitung jumlah kendaraan yaitu sepeda motor (MC), kendaraan ringan (LV), kendaraan berat (HV). Survei dilakukan oleh dua belas orang surveyor di titik pengamatan arah lalu lintas.
Kecepatan kendaraan yang dimaksud adalah kecepatan perjalanan, yaitu dengan cara jarak tempuh dibagi dengan waktu tempuh kendaraan. Survei kecepatan dilakukan dua kali, untuk kecepatan konstan dan kecepatan reduce speed. Survei driving behavior dilakukan dengan 2 tipe yaitu mengukur jarak kendaraan depan-belakang dan samping dengan keadaan kendaraan yang berhenti maupun kendaraan yang sedang melintas di jalan. Survei panjang antrian dilakukan dengan mengukur panjang kendaraan yang mengantri pada simpang, dari kendaraan depan hingga kendaraan belakang yang mengantri. Survei data primer dilakukan pada hari Selasa dan Kamis selama 8 jam yaitu pukul 06.00 09.00 WIB, pukul $11.00-14.00$ WIB, dan pukul 16.00 - 18.00 WIB. Data sekunder meliputi denah lokasi (maps) penelitian, dan jumlah penduduk. Tahap analisis data yaitu untuk mencari nilai antrian dan tundaan. Analisis dengan menggunakan bantuan microsoft excel serta menggunakan acuan Direktorat Jenderal Bina Marga, 1997 untuk perhitungan tundaan, panjang antrean dan derajat kejenuhan, serta dimodelkan menggunakan software VISSIM dengan perbandingan kondisi simpang tanpa pengaturan (dengan dan tanpa PTR), kondisi menggunakan alternatif simpang bersinyal (yang telah di analisis menggunakan pedoman Direktorat Jenderal Bina Marga). Lokasi penelitian yang digunakan dalam penelitian ini dapat dilihat pada Gambar 1 berikut. 


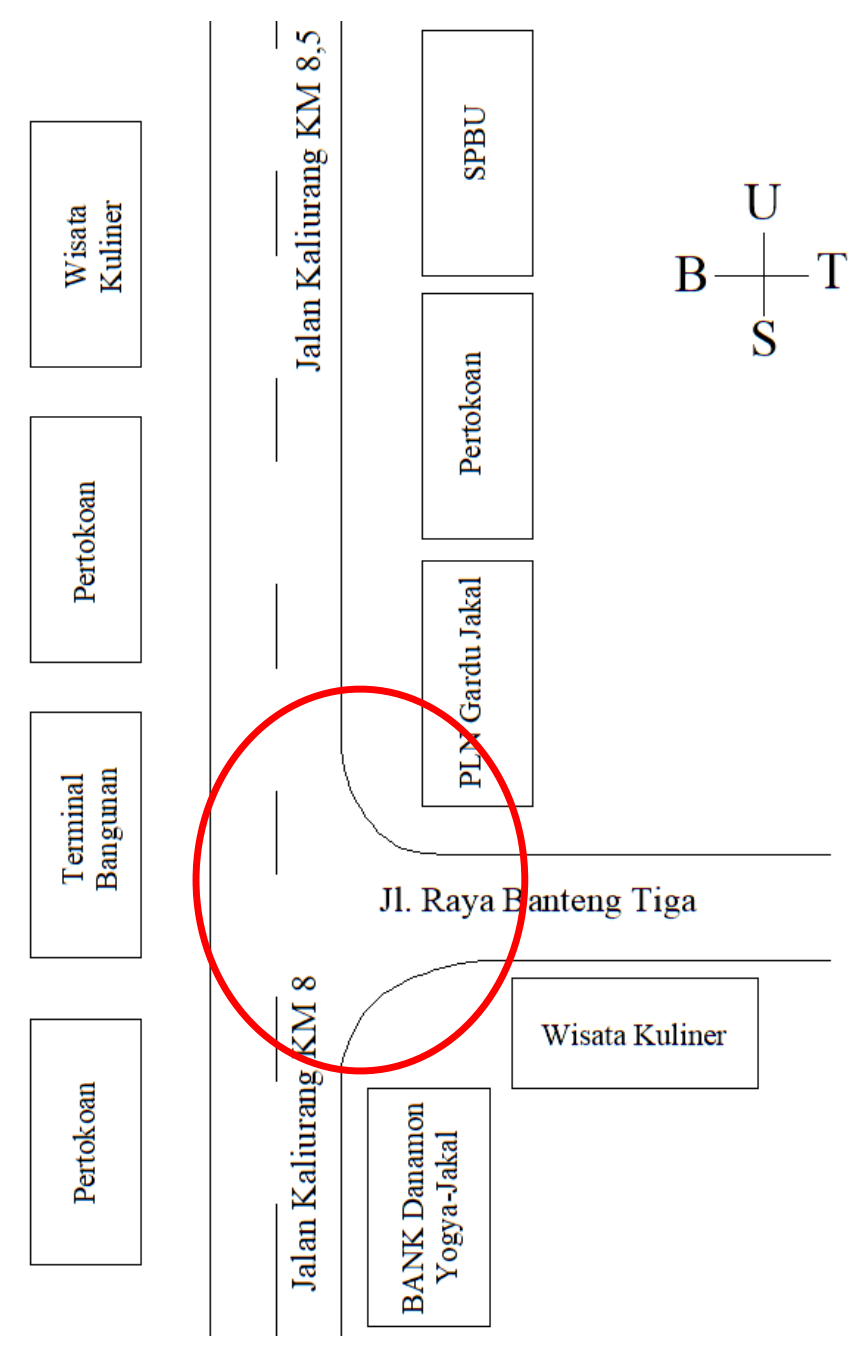

Gambar 1 Sketsa Simpang Tiga PLN Jakal Km 8

\section{HASIL PENELITIAN}

\section{Waktu Siklus Simpang Bersinyal}

Gambar diagram untuk waktu sinyal pada Simpang Tiga PLN Jakal Km 8 dapat dilihat pada Gambar 2 berikut.

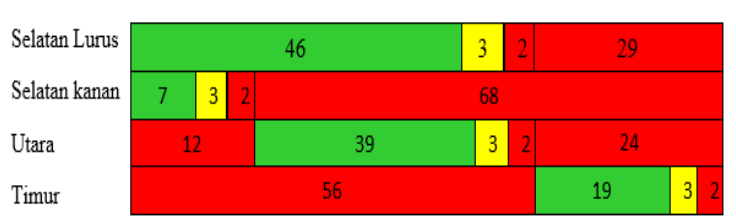

Gambar 2 Diagram Waktu Siklus Simpang PLN Jakal

\section{Validasi Menggunakan GEH Pada VISSIM}

Berdasarkan perhitungan menggunakan metode Geoffrey E. Havers $(G E H)$ diperoleh hasil $<5 \%$, dimana hasil tersebut mengartikan bahwa permodelan tidak ada masalah sehingga permodelan yang telah dibuat dapat digunakan. Hasil validasi tiap lengan dapat dilihat pada Tabel 1. 
Tabel 1 Hasil Validasi Tiap Lengan Kondisi tanpa pengaturan

\begin{tabular}{|c|c|c|c|c|}
\hline Lengan & $\begin{array}{c}\text { Volum } \\
\text { e } \\
\text { Tanpa } \\
\text { Penga } \\
\text { turan } \\
\text { Kend/ } \\
\text { Jam) }\end{array}$ & $\begin{array}{c}\text { Volume } \\
\text { VISSIM } \\
\text { Kend/J } \\
\text { am) }\end{array}$ & $\begin{array}{c}\text { GEH } \\
\%\end{array}$ & Keterangan \\
\hline Utara & 2404 & 2199 & 4,286 & Valid \\
\hline Timur & 996 & 902 & 3,065 & Valid \\
\hline Selatan & 2213 & 2004 & 4,560 & Valid \\
\hline
\end{tabular}

Berdasarkan Tabel 1 hasil validasi tiap lengan diperoleh dengan menggunakan persamaan GEH sebagai berikut. Berikut adalah perhitungan validasi lengan Utara.

$\mathrm{GEH}=\sqrt{\frac{(2199-2404)^{2}}{0,5 \times(2199+2404)}}=4,28$

Dengan menggunakan persamaan GEH, sehingga diperoleh hasil validasi lengan Utara sebesar 4,286\%, lengan Timur sebesar $3,065 \%$ dan lengan Selatan sebesar $4,560 \%$. Simpulan dari Tabel 1 yaitu semua lengan valid yang berarti permodelan diterima atau bisa digunakan.

\section{Analisis Kinerja Simpang}

Hasil dari analisis menggunakan VISSIM kondisi tanpa pengaturan ditunjukkan pada Tabel 2 dan Tabel 3.

Tabel 2 Output Panjang Antrean dan Waktu Tundaan Kondisi Tanpa Pengaturan.

\begin{tabular}{|c|c|c|c|}
\hline Lengan & $\begin{array}{c}\text { Qlen } \\
\text { (meter) }\end{array}$ & $\begin{array}{c}\text { Veh. } \\
\text { Delay } \\
\text { (detik) }\end{array}$ & $\begin{array}{c}\text { Tingkat } \\
\text { Pelayanan }\end{array}$ \\
\hline Utara & 323,013 & 18,148 & $\mathrm{C}$ \\
\hline Timur & 7,140 & 15,130 & $\mathrm{C}$ \\
\hline Selatan & 132,748 & 30,122 & $\mathrm{D}$ \\
\hline
\end{tabular}

Berdasarkan Tabel 2, tingkat pelayanan sesuai dengan nilai tundaan, yang mana klasifikasinya terdapat pada Peraturan Menteri Perhubungan Republik Indonesia Nomor 96 Tahun 2015. Pada kondisi tanpa pengaturan, tingkat pelayanan terburuk ada di lengan selatan di level D karena memiliki nilai tundaan tertinggi sebesar 30,122 detik. Sedangkan lengan dengan Panjang antrian terpanjang ada di lengan utara sebesar $323,013 \mathrm{~m}$.
Dengan adanya petugas tidak resmi, Panjang antrian dan nilai tundaan tertinggi berada di lengan yang sama walaupun dengan nilai yang lebih rendah sehingga menyebabkan lengan utara dan selatan memiliki tingkat pelayanan $\mathrm{C}$.

Tabel 3 Output Panjang Antrean dan Waktu Tundaan Kondisi dengan Petugas Tidak Resmi

\begin{tabular}{|c|c|c|c|}
\hline Lengan & $\begin{array}{c}\text { Qlen } \\
\text { (meter) }\end{array}$ & $\begin{array}{c}\text { Veh. } \\
\text { Delay } \\
\text { (detik) }\end{array}$ & $\begin{array}{c}\text { Tingkat } \\
\text { Pelayanan }\end{array}$ \\
\hline Utara & 310,41 & 15,42 & $\mathrm{C}$ \\
\hline Timur & 13,767 & 10,40 & $\mathrm{~B}$ \\
\hline Selatan & 243,08 & 23,57 & $\mathrm{C}$ \\
\hline
\end{tabular}

\section{Alternatif Permodelan Simpang}

Alternatif simpang PLN Jakal Km 8 yang dipilih yaitu menggunakan sinyal lalu lintas. Hasil analisis kondisi simpang menggunakan sinyal lalu lintas untuk ratarata nilai tundaan dan panjang antrean kondisi simpang menggunakan sinyal dapat dilihat pada Tabel 4 berikut.

Tabel 4 Output Panjang Antrean dan Waktu Tundaan Kondisi dengan Sinyal Lalu Lintas

\begin{tabular}{|c|c|c|c|}
\hline Lengan & $\begin{array}{c}\text { Qlen } \\
\text { (meter) }\end{array}$ & $\begin{array}{c}\text { Veh. Delay } \\
\text { (detik) }\end{array}$ & $\begin{array}{c}\text { Tingkat } \\
\text { Pelayanan }\end{array}$ \\
\hline Utara & 39,536 & 11,138 & $\mathrm{~B}$ \\
\hline Timur & 19,967 & 28,862 & $\mathrm{D}$ \\
\hline Selatan & 31,525 & 11,713 & $\mathrm{~B}$ \\
\hline
\end{tabular}

Berdasarkan Tabel 4 kondisi simpang dengan sinyal lalu lintas diperoleh rata-rata hasil tundaan dan panjang antrean sebesar 17,238 detik, sehingga tingkat pelayanan simpang dengan menggunakan sinyal yaitu C. Pengaturan menggunakan sinyal memiliki nilai tundaan lebih besar dari pada kondisi simpang dengan pengaturan PTR, akan tetapi pengaturan menggunakan sinyal lebih teratur dan mengurangi resiko kecelakaan. 


\section{PEMBAHASAN}

\section{Perbandingan Hasil Analisis Masing- Masing Kondisi Pengaturan}

Hasil analisis simpang pada kondisi tanpa pengaturan, dengan Petugas Tidak Resmi, dan sinyal dapat dilihat pada Tabel 5 dan Tabel 6.

Tabel 5 Hasil Analisis Masing-Masing Kondisi Pengaturan

\begin{tabular}{|c|c|c|c|c|}
\hline \multirow{2}{*}{ No } & Kondisi & \multicolumn{3}{|c|}{ Parameter } \\
\cline { 3 - 5 } Pengaturan & $\begin{array}{c}\text { Tundaan } \\
\text { (detik) }\end{array}$ & $\begin{array}{c}\text { Panjang } \\
\text { Antrean } \\
(\mathrm{m})\end{array}$ & $\begin{array}{c}\text { Tingkat } \\
\text { Pelayanan }\end{array}$ \\
\hline 1 & $\begin{array}{c}\text { Tanpa } \\
\text { PTR }\end{array}$ & 21,134 & 154,300 & $\mathrm{C}$ \\
\hline 2 & $\begin{array}{c}\text { Dengan } \\
\text { PTR }\end{array}$ & 16,463 & 189,086 & $\mathrm{C}$ \\
\hline 3 & $\begin{array}{c}\text { Dengan } \\
\text { Sinyal }\end{array}$ & 17,238 & 30,342 & $\mathrm{C}$ \\
\hline
\end{tabular}

Tabel 6 Perbedaan Prosentase MasingMasing Kondisi Terhadap Kondisi Tanpa Pengaturan

\begin{tabular}{|c|l|c|c|}
\hline No & $\begin{array}{c}\text { Kondisi } \\
\text { Pengaturan }\end{array}$ & $\begin{array}{c}\text { Perbedaan } \\
\text { Tundaan }\end{array}$ & $\begin{array}{c}\text { Perbedaan } \\
\text { Panjang } \\
\text { Antrean }\end{array}$ \\
\hline 1 & Tanpa PTR & $0 \%$ & $0 \%$ \\
\hline 2 & $\begin{array}{l}\text { Dengan } \\
\text { PTR }\end{array}$ & $-22,102 \%$ & $22,544 \%$ \\
\hline 3 & $\begin{array}{l}\text { Dengan } \\
\text { Sinyal }\end{array}$ & $-18,435 \%$ & $-80,336 \%$ \\
\hline
\end{tabular}

Perbandingan hasil tundaan dan panjang antrean masing-masing kondisi pengaturan akan disajikan pada Gambar 3 dan 4 sebagai berikut.

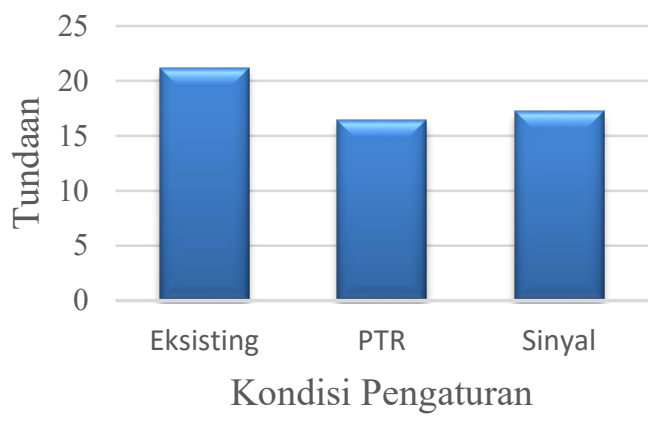

Gambar 3 Perbandingan Tundaan MasingMasing Pengaturan
Kondisi pengaturan dengan PTR, dan sinyal mengalami penurunan tundaan jika dibandingkan dengan kondisi tanpa pengaturan. Nilai tundaan dengan pengaturan PTR memiliki perbedaan $-22,102 \%$ dari kondisi tanpa pengaturan, sedangkan dengan pengaturan sinyal memiliki perbedaan $18,435 \%$ dari kondisi tanpa pengaturan. Kondisi pengaturan oleh PTR memiliki nilai tundaan yang lebih kecil dibandingkan dengan pengaturan sinyal maupun kondisi tanpa pengaturan, akan tetapi kondisi pengaturan dengan PTR akan menimbulkan resiko yang cukup besar. Untuk itu, pengaturan menggunakan sinyal merupakan alternatif yang yang diusulkan untuk perbaikan kinerja simpang. Walaupun memiliki nilai tundaan lebih besar dari pada kondisi simpang dengan pengaturan PTR, namun pengaturan menggunakan sinyal lebih teratur dan mengurangi resiko kecelakaan. Sedangkan berdasarkan Gambar 4, Nilai panjang antrean dengan pengaturan PTR memiliki perbedaan $22,544 \%$ dari kondisi tanpa pengaturan, sedangkan dengan pengaturan sinyal memiliki perbedaan $80,336 \%$ dari kondisi tanpa pengaturan. Kondisi simpang menggunakan sinyal menunjukkan bahwa panjang antrean mengalami penurunan dibandingkan kondisi tanpa pengaturan dan dengan PTR.

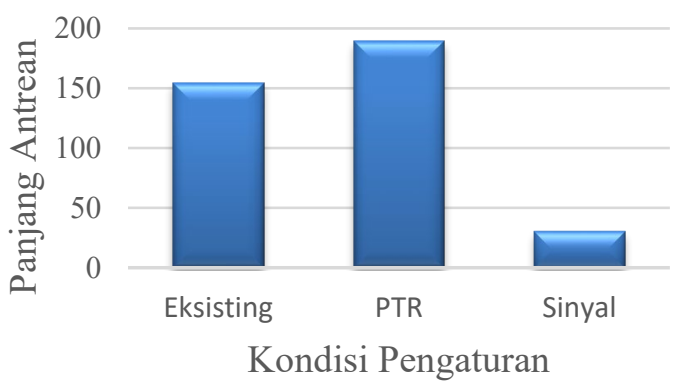

Gambar 4 Perbandingan Panjang Antrean Masing-Masing Pengaturan

\section{Perbandingan Tingkat Keselamatan Kondisi Tanpa Pengaturan, PTR, dan Simpang Bersinyal}

1. Tanpa Pengaturan

Banyaknya konflik pada kondisi tanpa pengaturan terjadi 9 titik, antara lain persilangan (crossing), penggabungan 
(merging), dan penyebaran (diverging) . pada simpang tiga PLN Jakal $\mathrm{km} 8$ memiliki 3 titik konflik crossing, 3 titik konflik merging, dan 3 titik konflik diverging. Detail titik konflik ditampilkan pada Gambar 5.

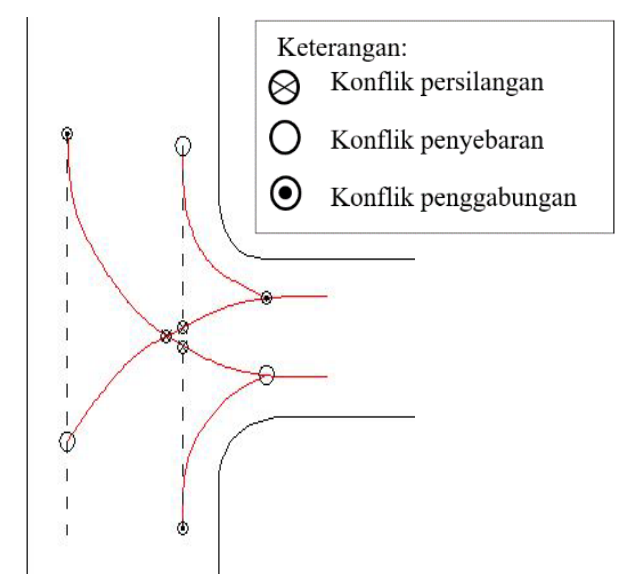

Gambar 5 Detail Konflik Kondisi Tanpa Pengaturan

2. Kondisi dengan PTR

Jumlah titik konflik yang terjadi kondisi dengan PTR yaitu 3 titik konflik penggabungan (merging), sedangkan titik konflik penyebaran (diverging) dan persilangan (crossing) tidak terdapat pada kondisi simpang dengan PTR. Titik konflik simpang kondisi PTR ditunjukkan pada Gambar 6.

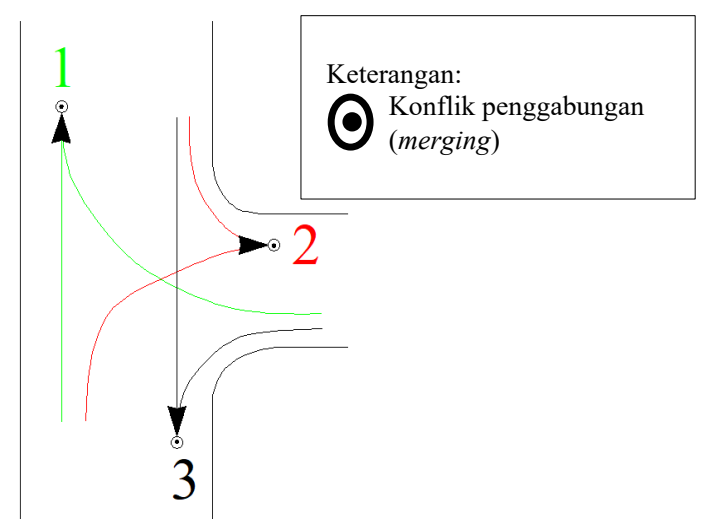

Gambar 6 Detail Konflik Kondisi dengan PTR

3. Kondisi Simpang Bersinyal

Kondisi simpang menggunakan sinyal tidak memiliki titik konflik, sehingga menggunakan sinyal merupakan salah satu alternatif yang bagus karena meminimalisir jumlah kecelakaan.

Dari Gambar 5 dan 6 , dapat diketahui jumlah konflik yang hasilnya direkap pada Tabel 7.

Tabel 7 Rekapitulasi Jumlah Konflik Kondisi Tanpa Pengaturan, PTR dan Sinyal

\begin{tabular}{|c|c|c|c|}
\hline \multirow{2}{*}{$\begin{array}{c}\text { Jenis } \\
\text { Konflik }\end{array}$} & \multicolumn{3}{|c|}{ Jumlah Konflik } \\
\cline { 2 - 4 } & $\begin{array}{c}\text { tanpa } \\
\text { pengaturan }\end{array}$ & PTR & Sinyal \\
\hline Crossing & 3 & 0 & 0 \\
\hline Merging & 3 & 3 & 0 \\
\hline Diverging & 3 & 0 & 0 \\
\hline Total & 9 & 3 & 0 \\
\hline
\end{tabular}

Jumlah konflik pada kondisi tanpa pengaturan yaitu 9, kondisi simpang ada PTR memiliki total jumlah konflik 3 dan dengan menggunakan sinyal tidak memiliki titik konflik.

\section{KESIMPULAN}

1. Kinerja simpang tiga PLN Jakal $\mathrm{km} 8$ tanpa pengaturan PTR menghasilkan nilai tundaan sebesar 21,134 detik, dengan tingkat pelayanan $\mathrm{A}$ dan panjang antrean $154,300 \mathrm{~m}$. Kondisi simpang tanpa pengaturan menghasilkan nilai tundaan yang kecil, tetapi resiko yang dihasilkan cukup besar yaitu kecelakaan lebih tinggi pada daerah konflik di simpang tanpa pengaturan jika dibandingkan dengan diatur oleh petugas maupun sinyal.

2. Kinerja simpang tiga PLN Jakal $\mathrm{km} 8$ dengan pengaturan PTR menghasilkan nilai tundaan sebesar 16,463 detik, dengan tingkat pelayanan $\mathrm{C}$ dan panjang antrean $189,084 \mathrm{~m}$. Kondisi simpang dengan pengaturan PTR memiliki tingkat pelayanan cukup baik, namun pengaturan PTR bersifat random dan tidak rapi dapat menyebabkan kecelakaan.

3. Kinerja simpang tiga PLN Jakal $\mathrm{km} 8$ dengan pengaturan sinyal menghasilkan nilai tundaan 17,238 detik, dengan tingkat pelayanan $\mathrm{B}$, dan panjang antrean 30,342 m. Nilai tundaan pengaturan sinyal lebih besar dari kondisi simpang tanpa pengaturan, akan tetapi dengan 
pengaturan sinyal dipilih sebagai alternatif solusi karena lebih aman dan teratur sehingga mengurangi resiko terjadinya kecelakaan.

4. Jumlah titik konflik simpang kondisi tanpa pengaturan yaitu 9 dan kondisi dengan PTR berjumlah 3. Sedangkan kondisi simpang dengan sinyal tidak terdapat titik konflik. Walaupun jumlah nilai tundaan kondisi simpang dengan PTR lebih bagus, namun kondisi simpang dengan PTR memiliki titik konflik yang dapat menimbulkan kecelakaan, sehingga kondisi simpang menggunakan sinyal merupakan alternatif yang baik untuk simpang Tiga PLN Jakal $\mathrm{km} 8$ dalam meminimalisir jumlah kecelakaan karena tidak memiliki titik konflik.

\section{DAFTAR PUSTAKA}

Al Qadri, M. (2006), Pengaruh Petugas Resmi dan Petugas Tidak Resmi Terhadap Lalu Lintas di Persimpangan Prioritas (Studi Kasus Simpang Kompas Kabupaten Bekasi). Tesis. (Tidak Diterbitkan). Universitas Gadjah Mada. Yogyakarta.

Alhadar, A. (2011), Analisis Kinerja Jalan Dalam Upaya Mengatasi Kemacetan Lalu Lintas Pada Ruas Simpang Bersinyal Di Kota Palu, Jurnal SMARTe, vol. 9, no. 4, pp 327 - 336. Palu.

Antony, N.D. (2019), Peneliti Transportasi Unhas Jelaskan Sebab Pak Ogah Buat Macet Makassar, detikNews, diakses $\quad 16 \quad$ Februari https://m.detik.com/news/berita/d4821889/peneliti-transportasiunhas-jelaskan-sebab-pak-ogahbuat-macet-makassar.

Antony, N.D. (2020), Pak Ogah Buat Macet Makassar Ketua DPRD: Dishub Stand By Di Jalan. detikNews, diakses $\quad 16 \quad$ Februari, https://news.detik.com/berita/d4899099/pak-ogah-buat-macetmakassar-ketua-dprd-dishub-standby-di-

jalan?_ga $=2.30657535 .1167882986$
$.1581812864-$ 663432020.1581812864).

Arisandi, Y. (2015), Analisis Kinerja Simpang Tak Bersinyal Di Kota Malang (Studi Kasus Simpang Pada Ruas Jl. Basuki Rahmat Kota Malang), Jurnal Penelitian Transportasi Darat. vol. 17, no 2, pp 111-118. Jakarta.

Aryandi, R.D. dan Munawar A. (2014), Penggunaan Software Vissim Untuk Analisis Simpang Bersinyal: Studi Kasus Simpang Mirota Kampus Terban Yogyakarta. 17th FSTPT International Symposium, 22-24 Agustus. Universitas Jember. Jember.

Direktorat Jenderal Bina Marga (1997), Manual Kapasitas Jalan Indonesia (MKJI), Penerbit Departemen Pekerjaan Umum. Jakarta.

Direktorat Jenderal Perhubungan Darat (1996), Buku Menuju Tertib Lalu Lintas Dan Angkutan Jalan Yang Tertib. Jakarta.

Kulo, E.P. dkk. (2017), Analisa Kinerja Simpang Tak Bersinyal Dengan Analisa Gap Acceptance Dan MKJI 1997, Jurnal Sipil Statik, vol.5, no.2, pp 2337-6732. Manado.

Morlok, E.K. (1988), Pengantar Teknik dan Perencanaan Transportasi, Erlangga. Jakarta.

Nursalam dan Akhir, M. (2016), Persepsi Masyarakat Terhadap Eksistensi Pak Ogah. Jurnal Equilibrium Pendidikan Sosiologi, vol. III, no. 2, pp 224. Makassar.

Pemerintah Republik Indonesia (2015), Peraturan Menteri Nomor 96 Tahun 2015 tentang Pedoman Pelaksanaan Kegiatan Manajemen dan Rekayasa Lalu Lintas. Sekretariat Negara. Jakarta.

Pemerintah Republik Indonesia (2009). Undang - Undang Nomor 22 Tahun 2009 tentang Lalu Lintas dan Angkutan Jalan. Sekretariat Negara. Jakarta.

Romadhona, P.J. dan Yuliansyah, A. (2018), Perbandingan Kinerja Simpang dengan Pengaturan Petugas Tidak Resmi, Tanpa 
Pengaturan, dan Pengaturan Sinyal (Studi Kasus Simpang Kronggahan Sleman), Jurnal Potensi Politeknik Negri Bandung. Bandung

Saputro, T.L. dkk. (2018), Kajian Simpang Tiga Tak Bersinyal Kariangau KM. 5,5 Kelurahan Karang Joang Balikpapan Utara Menggunakan Permodelan VISSIM menjadi Simpang Bersinyal, Jurnal Teknologi Terpadu, vol. 6, no. 1, pp 2338 - 6649. Balikpapan Utara.

Sugiharti, P. dan Widodo, W. (2013), Analisis Kinerja Simpang Tak Bersinyal (Studi Kasus: Simpang 3 Tak Bersinyal Jl. Raya Seturan-Jl. Raya Babarsari-Jl. Kledokan, Depok, Sleman, Yogyakarta), Konferensi Nasional Teknik Sipil 7. Surakarta.

Tahjudin, I. (2017). Pemodelan Simpang Tak Bersinyal Menjadi Simpang Bersinyal Menggunakan Software Vissim. Tugas Akhir. (Tidak Diterbitkan). Universitas Muhammadiyah Yogyakarta. Yogyakarta.

Tirtana, G.A. (2012), Pak Ogah Ibarat Buah Simalakama, Radar Jogja, diakses 16 Februari 2020, https://radarjogja.jawapos.com/201 8/12/26/pak-ogah-ibarat-buahsimalakama/.

Utama, D. (2006), Evaluasi Kinerja Simpang Tak Bersinyal Antara Jalan Sultan Hamengkubuwono 9 Dan Jalan Cakung Cilincing Raya, Jurnal Sains dan Teknologi Indonesia, vol.8, no.2, pp 75-80. Jakarta.

Verawanti dan Romadhona, P.J. (2019), Dampak Petugas Pengatur Lalu Lintas Terhadap Kinerja Simpang 4 Tak Bersinyal Jalan Agro Bougenvile (Lembah UGM) Yogyakarta, Jurnal Teknisia Universitas Islam Indonesia. Yogyakarta.

Wardhana, W.R.S dan Hartantyo D.S. (2016), Analisa Persimpangan Tak Bersinyal Pada Persimpangan Tiga
Lengan, Jurnal CIVILLa, vol.1, no.2, pp 2503-2399.

YUD, 2018, Dishub: 2019, Bekasi Bebas "Pak Ogah", Berita Satu, Diakses 16 Februari 2020, https://www.beritasatu.com/megap olitan/473844/dishub-2019-bekasibebas-pak-ogah. 